\title{
The Impact of Celebrity Endorsement on Brand Affection and Purchase Intention: The Mediating Role of Word of Mouth
}

\section{Farida Saleem*}

\begin{abstract}
Celebrity endorsement is widely used as an advertising technique. This study examines three dimensions of celebrity endorsement, including trustworthiness, expertise and attractiveness, as predictors of positive word of mouth by consumers. It also gauges the impact of word of mouth on purchase intention and brand affection in terms of the role it plays as a mediating construct between celebrity endorsement and consumers' behavioral outcomes. The study uses a sample of 369 respondents to test a structural equation model. Its results reveal that the fully mediated model is superior to the partially mediated model and that trustworthiness is the most important attribute of celebrity endorsement, yielding positive consumer behavior.
\end{abstract}

Keywords: celebrity endorsement, word of mouth, purchase intentions, brand affection.

JEL classification: M31, M37.

\section{Introduction}

Celebrity endorsement has long been a popular marketing tool and is recognized as a "widespread and essential" phenomenon of "modernday marketing" (Biswas, Hussain \& O'Donnell, 2009). It is also deemed a pragmatic marketing communication strategy (Erdogan, 1999). Sponsorship advertising can involve different kinds of endorsers, including easily identifiable celebrities, with whom people are familiar, ordinary consumers, companies or animated characters (Stout \& Moon, 1990). Arguably, using well-known or eminent people to endorse a product is most likely to attract consumer interest (Daneshvary \& Schwer, 2000).

McCracken (1989) defines a celebrity endorser as "any individual who enjoys public recognition and who uses this recognition on behalf of a consumer good by appearing with it in an advertisement." Such ads are

\footnotetext{
* Associate Professor University of Lahore, Chanab Campus, Gujrat
} 
known as marcoms and allow celebrities to bring "their own culturally related meanings [to the ad] ... irrespective of the required promotional role." Advertisers choose to use celebrities to communicate the attributes and benefits of their products because celebrity endorsement is considered an effective promotional strategy (Rashid, Nallamuthu \& Sidin, 2002). The last two decades have seen a sharp rise in this marketing trend and it has become an important marketing strategy among firms with respect to almost all types of media (Levin, 1988). In 1977, about 15 percent of television commercials in the US featured celebrities (Fireworker \& Friedman, 1977). By 1985, this percentage had increased to 20 percent (Sherman, 1985). Currently, about 30 percent of advertisements feature celebrities.

Among other aspects, the literature on sponsorship advertising and celebrity endorsement looks at the influence of sponsorship on consumer behavior, that is, purchase intentions and loyalty (Lafferty \& Goldsmith, 1999), the reasons for sponsorship on behalf of corporations in sports (Marshall \& Cook, 1992), its influence on attitudes and behavior in view of experienced or similar endorsers (Feick \& Higie, 1992), and the perceived compatibility of the endorser with the product (Till \& Busler, 1998). The aim of this study is to provide a better understanding of the processes underlying celebrity endorsement, including its impact on purchase intention and brand affection among consumers, and to investigate the mediating effect of word of mouth (WOM) in the relationship between celebrity endorsement, purchase intention and brand affection in Pakistan.

Considerable importance is given to the use of celebrity endorsement as an effective strategy to communicate brand message and influence consumers' purchase intentions as well as other brand attributes, using control variables such as brand involvement, brand image and brand awareness. However, the use of other communication strategies incorporated with celebrity endorsement in a specific cultural context needs further study. In this case, we look at the limitations of WOM to investigate the gap identified by Wang and Yang (2010), who explore how the relationship between celebrity endorsement and consumer attributes is mediated by WOM communication.

\section{Literature Review}

The nature of the celebrity endorser affects how consumers perceive the attributes and benefits of the product being endorsed, thereby increasing its acceptability among customers. Since they trust the celebrity, people tend to transfer their perception of the celebrity to the brand being 
endorsed (Biswas, Biswas \& Das, 2006). Thus, celebrity endorsement is considered an effective marketing technique by which marketers not only promote and persuade, but also make their product or brand more desirable with the appearance of a celebrity. Customers who see celebrities as role models are inclined to modify their behavior to match that of the latter (Ahmed, Farooq \& Iqbal, 2014). This process influences consumer attitudes and perceptions.

The significance of celebrity endorsement in brand communication lies in the idea that celebrities can add value not only to the product they are endorsing, but also to the brand (Okorie, Oyedepo \& Akhidenor, 2012). This entails taking advantage of public recognition: celebrities appear in advertisements associated with different products and services because they draw consumers' attention and aid product or brand recall (Agrawal \& Kamakura, 1995). The literature shows that celebrity endorsement makes a given brand or product distinguishable from others and creates a positive brand image (Petty, Cacioppo \& Schumann, 1983). The considerable impact that celebrities can have on people's minds - and thereby on consumer behavior - makes such advertisements more persuasive (Choi \& Rifon, 2007) and thus enhances customers' purchase intentions toward that brand (Friedman \& Friedman, 1978).

Accordingly, advertisers try to match the personality of a celebrity to the attributes of the product being endorsed because this congruency focuses on the customer's senses and helps create a positive brand attitude (Kamins, 1989). Pradhan, Duraipandian and Sethi (2016) investigate the celebrity congruence model and find that brand-celebrity and user-brand-personality congruence is significantly associated with brand attitude and brand purchase intention. Zahaf and Anderson (2008) observe that celebrities perceived as being credible and trustworthy and who are known for their expertise in a given area, can influence buyers' willingness to purchase a product far more effectively than the degree of congruency between that product and the celebrity. Thus, advertisers hire celebrities to endorse brands or products based on their attractiveness (Baker \& Churchill, 1977) as well as their credibility (Sternthal, Dholakia \& Leavitt, 1978).

Social learning theory, proposes Bandura (1967), helps explain human cognitive behavior - in this context, how role models can have a significant impact on people's behavior, through an experiment testing aggressive behavior among children. The study shows that a group of children who were exposed to a certain model in a cartoon, shown attacking a doll verbally and physically, behaved twice as aggressively as 
children who had been exposed to a nonaggressive model. This theory posits that individuals learn to behave in a certain way by observing the actions of their role models (Westen, 1999).

According to Bergkvist and Zhou, celebrity endorsement "is an agreement between an individual who enjoys public recognition [the celebrity] ... and an entity [the brand] ... for the purpose of promoting the entity" (2016, p. 664). Similarly, Fraser and Brown (2002) describes a role model as an individual or person whose beliefs, ideas, attitudes, perception, values, actions and behavior are observed keenly by others. People then imitate them and implement their (the role model's) behavior in their routine lives. This underscores the social influence of celebrities through the processes of identification and persuasion.

Feilitzen and Linne (1975) argue that people tend to identify most strongly with media characters or celebrities, even imitating their styles and mannerisms to become more like them (McGuire, 1974). Celebrity endorsement positively affects consumers' attitudes toward a product relative to when it was not endorsed by a celebrity (Knoll \& Matthes, 2017). Martin and Bush (2000) also examine the influence of television stars, media entertainers, sports athletes and parents as role models on purchase intention and consumption attitudes. Similarly, Fraser and Brown (2002) use the example of musician Elvis Presley to show how celebrities are seen as role models and how their values, ideas and beliefs can thus be modified at a social and personal level. This applies particularly to purchase behavior among teenagers.

\section{Study Hypotheses}

This section develops the study's hypotheses concerning celebrity endorsement and WOM, purchase intention and brand affection.

\subsection{Celebrity Endorsement and WOM}

WOM is a key factor in consumer decision making (Mangold, Miller \& Brockway, 1999). It refers to the face-to-face interaction between a sender and receiver by which one influences the attitude, perception and behavior of the other, whether in a positive or negative sense (Sweeny, Soutar \& Mazzarol, 2008).

WOM is used to assess consumers' post-purchase behavior (Swan \& Oliver, 1989) and is often deemed a better, more authentic source of 
information or feedback about a product than the information propagated by the firm itself. This is because the sender generating WOM is independent of the company to which that product belongs and is, therefore, not biased (Silverman, 2001). People prefer to rely on the information they receive through informal and/or face-to-face interaction (for example, from other consumers) when making purchase decisions rather than relying on formal advertisements (Bansal \& Voyer, 2000) because their fellow consumers are more likely to provide objective information (Schiffman \& Kanuk, 2000).

The literature identifies three characteristics of WOM messages: (i) the favorableness or valence of the message: its positive or negative aspects; (ii) its emotive aspect: the depth, richness, vividness, intensity and emotional appeal used to shape people's values with convincing results; and (iii) its cognitive aspect: what is being said on the basis of rational appeal (Harrison-Walker, 2001; Mazzarol, Sweeney \& Soutar, 2007).

Since WOM consists of information based on opinion, it can be positive or negative. WOM may convey pleasant, satisfying and favorable experiences to others when it is positive, or unpleasant experiences thereby reducing the worth and value of that product - when it is negative (Anderson, 1998). Moreover, it is not necessary that people generate and receive only positive or only negative WOM - most consumers encounter mixed WOM during their interaction with others (Wang, 2011). However, marketers are concerned with spreading positive WOM and reducing or avoiding negative WOM, given the latter's role in the success of a product among consumers (Day, 1971). Bush, Martin and Bush (2004) observe that positive WOM is more likely to be generated when a product or service has been endorsed by a popular athlete or sports celebrity. According to Ohanian (1991), for a truly effective celebrity endorsement, the chosen celebrity endorser should not only be knowledgeable, but also experienced and qualified enough to be deemed an expert in that area by consumers.

Marketers have traditionally examined three characteristics of endorsers, including attractiveness, trustworthiness and expertise. Attractiveness can refer either to the physical attractiveness of the endorser or to perceived similarities between the endorser and receiver (Feick \& Higie, 1992; McCracken, 1989). Feick and Higie (1992) find that, when individual taste is the more dominant, a consumer's similarity with the endorser becomes more important in identifying preferences for products or services. Expertise implies that the endorser is knowledgeable about the product or service $\mathrm{s} / \mathrm{he}$ is endorsing. This plays a significant role when 
there is no or little variation in tastes and preferences among consumers. Finally, the trustworthiness of the endorser is an important indicator of his or her credibility (Friedman, Termini \& Washington, 1976). For consumers, therefore, the perception that the endorser is knowledgeable, trustworthy and attractive makes him or her a credible source of information.

Based on the literature reviewed above, the study's first three hypotheses are:

- H1: The attractiveness of a celebrity endorser creates positive WOM among consumers.

- H2: The expertise of a celebrity endorser creates positive WOM among consumers.

- H3: The trustworthiness of a celebrity endorser creates positive WOM among consumers.

\subsection{WOM and Purchase Intention}

The cost incurred by companies to attract new customers is far greater than that of retaining existing customers (Spreng, Harrell \& Mackoy, 1995). Hence, purchase intention remains an important area of enquiry for researchers and marketers. WOM communication is considered one of the most important determinants of customers' attitudes and buying intentions (Xia \& Bechwati, 2008; Sen \& Lerman, 2007; Jalilvand \& Samiei, 2012). WOM messages are, therefore, a key reference point when making purchase decisions (Jalilvand \& Samiei, 2012).

Positive WOM generated by immediate social groups, including family and friends, in the form of suggestions and advice, helps reduce perceived risk (Cox, 1967), thereby enhancing the buyer's purchase decision. WOM has been found to increase revenue generation for many products, including automobiles (Swan \& Oliver, 1989) and films (Mizerski, 1982). Positive WOM events lead to more favorable consumer attitudes and behavior (Hamer, Liu \& Sudharshan, 1999). Based on these findings, the study proposes $(\mathrm{H} 4)$ that positive WOM has a significant impact on purchase intention among customers.

\subsection{WOM and Customer Brand Affection}

Brand affection is the "emotion or affective reaction of the consumer towards a product or brand, representing the direct or overall evaluation of the consumer towards the product" (Wu \& Wang, 2011, p. 453). While 
celebrity endorsement has no direct impact on brand attributes (Bergkvist, Hjalmarson \& Mägi, 2016), consumers may be influenced by the attitude of the endorsing celebrity toward a given brand (Ling \& Liu, 2008). Thus, when a highly credible celebrity is featured in an advertisement, customer attitudes toward that brand are more likely to be positive (Wu \& Wang, 2011). In turn, positive WOM is likely to attract new customers and retain existing ones (Reichheld \& Sasser, 1990). In this sense, it affects brand attitudes as well as brand affection (Wu \& Wang, 2011). Based on these findings, the study's fifth hypothesis (H5) is that positive WOM has a significant impact on brand affection.

\section{Methodology}

Three dimensions of celebrity endorsement - attractiveness, expertise and trustworthiness - were measured, using a scale adapted from Ohanian (1990). In all, 14 items were used to gauge celebrity endorsement, with four items measuring the endorser's attractiveness and five items each measuring expertise and trustworthiness. WOM was measured using three items adapted from Maxham (2001). Brand affection and purchase intention were measured using three items each adapted from Chaudhuri and Holbrook (2001) and Shukla (2010), respectively. All questions related to the study variables were measured using a five-point Likert scale ranging from 1 for "strongly disagree" to 5 for "strongly agree".

A self-administered questionnaire was developed, pertaining to (i) celebrity endorsement, (ii) WOM, (iii) brand affection, (iv) purchase intention and (v) demographics. The data was collected through online survey forms as well as hard copies of the questionnaire distributed among a conveniently available sample. A total of 500 hard copies were distributed at different universities in Rawalpindi and Islamabad. Of these, 225 useable questionnaires were returned. Another 144 online survey forms were filled by respondents through social media websites such as Facebook, Instagram and Linkedin. A total of 369 useable questionnaires was received.

\section{Data Analysis}

SPSS software was used to carry out a descriptive analysis of the data, while AMOS was used to run the structural equation model. The latter entailed a two-step incremental approach: fitting the measurement model and then fitting the structural model. 


\subsection{Sample Profile}

Of a total sample of 369 respondents, 63 percent (234) were female and 37 percent (135) were male. The bulk of respondents (almost 58 percent) were students, most of them aged 21-31 (52.3 percent). Most respondents were unmarried (62.6 percent). Table 1 gives the mean, standard deviation, internal consistency measures and inter-correlation of the study's endogenous and exogenous variables.

Table 1: Descriptive analysis, correlation matrix and AVE

\begin{tabular}{|c|c|c|c|c|c|c|c|c|c|}
\hline Latent construct & $\begin{array}{l}\text { No. of } \\
\text { items }\end{array}$ & Mean & SD & 1 & 2 & 3 & 4 & 5 & 6 \\
\hline Attractiveness & 4 & 2.17 & 0.93 & 0.73 & & & & & \\
\hline Trustworthiness & 5 & 2.65 & 0.85 & $\begin{array}{l}0.41^{*} \\
(0.17)\end{array}$ & 0.68 & & & & \\
\hline Expertise & 5 & 2.37 & 0.82 & $\begin{array}{l}0.50^{*} \\
(0.25)\end{array}$ & $\begin{array}{l}0.59^{*} \\
(0.35)\end{array}$ & 0.53 & & & \\
\hline Word of mouth & 3 & 2.55 & 0.99 & $\begin{array}{l}0.31^{*} \\
(0.09)\end{array}$ & $\begin{array}{l}0.43^{*} \\
(0.18)\end{array}$ & $\begin{array}{l}0.41^{*} \\
(0.17)\end{array}$ & 0.75 & & \\
\hline Brand affection & 2 & 2.62 & 1.10 & $\begin{array}{l}0.34^{*} \\
(0.11)\end{array}$ & $\begin{array}{l}0.35^{*} \\
(0.12)\end{array}$ & $\begin{array}{l}0.34^{*} \\
(0.11)\end{array}$ & $\begin{array}{l}0.69^{*} \\
(0.48)\end{array}$ & 0.80 & \\
\hline $\begin{array}{l}\text { Purchase } \\
\text { intention }\end{array}$ & 3 & 2.75 & 1.05 & $\begin{array}{l}0.45 \\
(0.20)\end{array}$ & $\begin{array}{l}0.46 \\
(0.21)\end{array}$ & $\begin{array}{l}0.35 \\
(0.12)\end{array}$ & $\begin{array}{l}0.70 \\
(0.49)\end{array}$ & $\begin{array}{l}0.65 \\
(0.42)\end{array}$ & 0.77 \\
\hline
\end{tabular}

Note: ${ }^{*} \mathrm{p}<0.01$, AVE given in bold, shared variance given in parentheses.

Source: Author's estimates.

All the variables have a reliability coefficient that falls within an acceptable range ( 0.07 or above), as suggested by Nunnally and Bernstein (1994). All the correlations are significant and take the direction expected. None of the coefficients is greater than 0.8 , indicating that there is no multicollinearity in the dataset.

\subsection{Validity Analysis}

We gauge the construct validity based on the factor loading value of each observed variable in its respective latent construct. Discriminant validity is checked using Fornell and Larcker's (1981) criteria. The value of the average variance extracted (AVE) for all observed constructs is less than the value of the squared multiple correlation in each case. This confirms the construct and discriminant validities of the data (Table 1).

\subsection{Reliability Analysis}

Table 2 confirms the reliability of the data, using Cronbach's alpha and composite reliability (CR) indices. The proposed hypotheses are tested 
using a structural equation model. Following Anderson and Gerbing (1988), we carry out a two-step analysis. This entails establishing the suitability and reliability of the measurement model and then testing the structural model. Using a three-factor model for celebrity endorsement warrants a confirmatory factor analysis (CFA). Since WOM is taken as the mediating factor, we also conduct a specific mediation analysis.

Table 2: CFA results for observed and latent constructs

\begin{tabular}{|c|c|c|c|c|}
\hline Latent and observed constructs & $\beta$ & $\alpha$ & CR & AVE \\
\hline Attractiveness & & 0.912 & 0.91 & 0.72 \\
\hline AT1 & 0.845 & & & \\
\hline AT2 & 0.815 & & & \\
\hline AT3 & 0.872 & & & \\
\hline AT4 & 0.872 & & & \\
\hline Trustworthiness & & 0.896 & 0.89 & 0.68 \\
\hline TW1 & 0.818 & & & \\
\hline TW2 & 0.825 & & & \\
\hline TW3 & 0.842 & & & \\
\hline TW4 & 0.821 & & & \\
\hline Expertise & & 0.853 & 0.85 & 0.53 \\
\hline EX1 & 0.711 & & & \\
\hline EX2 & 0.808 & & & \\
\hline EX3 & 0.764 & & & \\
\hline EX4 & 0.649 & & & \\
\hline EX5 & 0.685 & & & \\
\hline Word of mouth & & 0.896 & 0.90 & 0.75 \\
\hline WOM1 & 0.819 & & & \\
\hline WOM2 & 0.897 & & & \\
\hline WOM3 & 0.873 & & & \\
\hline Brand affection & & 0.885 & 0.88 & 0.77 \\
\hline BA1 & 0.922 & & & \\
\hline BA2 & 0.864 & & & \\
\hline Purchase intention & & 0.908 & 0.91 & \\
\hline PI1 & 0.887 & & & \\
\hline PI2 & 0.817 & & & \\
\hline PI3 & 0.848 & & & \\
\hline
\end{tabular}

Note: $\alpha=$ Cronbach's alpha, $\mathrm{CR}=$ composite reliability, $\mathrm{AVE}=$ average variance extracted. Source: Author's estimates.

The fit of the measurement and structural models is verified using different fit indices, including the $\chi^{2}$ statistic, comparative fit index (CFI), 
adjusted goodness-of-fit index (AGFI), goodness-of-fit index (GFI), root mean square error of approximation (RMSEA) and root mean square residual (RMR). There is still some debate over the acceptable cutoff values for adequate fit (see $\mathrm{Hu} \&$ Bentler, 1999; Cheung \& Rensvold, 2002). However, we consider the following recommendations: CFI $>0.95$ and $\mathrm{RMR}<0.08$, following $\mathrm{Hu}$ and Bentler (1999); GFI = 0.95 and AGFI = 0.90, following Miles and Shevlin (1998). While MacCallum, Browne and Sugawara (1996) suggest an RMSEA of below 0.08, Hu and Bentler propose a cut-off value close to 0.06 and Steiger (2007) indicates a rigorous upper limit of 0.07 .

\subsection{CFA (Measurement) Model}

Table 3 compares the proposed six-factor model with other possible CFA models.

Table 3: Comparison of CFA models with six-factor model

\begin{tabular}{|c|c|c|c|c|c|c|}
\hline CFA model & $\begin{array}{c}\chi^{2} \\
\text { (df) } \\
\text { df } / \chi^{2}\end{array}$ & CFI & RMR & GFI & RMSEA & $\begin{array}{c}\text { Comparison with six- } \\
\text { factor model } \\
\Delta \chi_{2}(\mathrm{df})\end{array}$ \\
\hline Three-factor & $\begin{array}{c}1,827 \\
(185) \\
9.8\end{array}$ & 0.699 & 0.120 & 0.613 & 0.155 & $\begin{array}{c}1,426 \\
(12)\end{array}$ \\
\hline Four-factor & $\begin{array}{c}1,580 \\
(182) \\
8.2\end{array}$ & 0.744 & 0.113 & 0.636 & 0.145 & $\begin{array}{c}1,179 \\
(9)\end{array}$ \\
\hline Six-factor & $\begin{array}{c}401 \\
(173) \\
2.3\end{array}$ & 0.953 & 0.440 & 0.910 & 0.060 & \\
\hline
\end{tabular}

Source: Author's estimates.

These include a three-factor model containing all the items measuring celebrity endorsement as one construct, and purchase intention and brand affection as one construct; and a four-factor model that loads the items measuring attractiveness, trustworthiness and expertise onto one factor, with purchase intention, brand affection and WOM as separate factors. The results in Table 3, including the ${ }^{*} 2$ difference tests, show that the six-factor model has better fit indices than the other models.

\subsection{Full Measurement Model}

A full CFA is conducted to incorporate the observed variables (items of scales) and their latent constructs. This entails using the 
maximum likelihood estimation method. Since all the observed variables are loaded well - with regression weights greater than 0.6 - on their respective latent constructs, none of the items is removed from the analysis at this stage. The AVE and CR are calculated using the CFA measurement model outputs (see Table 2).

\subsection{Structural Model Analysis}

The proposed model is a fully mediated model with no direct path between celebrity endorsement, purchase intention and brand affection. However, to establish that this model is better than a partially mediated one, with direct paths between these variables, we compare the two. Table 4 shows that four of the six paths between celebrity endorsement, purchase intention and brand affection are insignificant, thereby confirming the superiority of the fully mediated model.

Table 4: Comparison of fully and partially mediated structural models

\begin{tabular}{lcccccc}
\hline & \multicolumn{3}{c}{ Fully mediated model } & \multicolumn{3}{c}{ Partially mediated model } \\
\cline { 2 - 7 } Proposed \\
relationship & $\begin{array}{c}\text { Standardized } \\
\text { regression } \\
\text { weight }\end{array}$ & t-value & p-value & $\begin{array}{c}\text { Standardized } \\
\text { regression } \\
\text { weight }\end{array}$ & t-value & $\begin{array}{c}\text { p- } \\
\text { value }\end{array}$ \\
\hline TR $=>$ WOM & 0.298 & 4.426 & 0.000 & 0.283 & 0.408 & 0.000 \\
$\mathrm{AT}=>$ WOM & 0.154 & 2.595 & 0.009 & 0.109 & 1.785 & 0.074 \\
$\mathrm{EX}=>$ WOM & 0.166 & 2.399 & 0.016 & 0.183 & 2.523 & 0.012 \\
WOM => PI & 0.739 & 13.692 & 0.000 & 0.621 & 11.337 & 0.000 \\
WOM => BA & 0.712 & 14.178 & 0.000 & 0.659 & 11.845 & 0.000 \\
$\mathrm{AT}=>$ PI & & & & 0.249 & 5.025 & 0.000 \\
$\mathrm{AT}=>$ BA & & & & 0.114 & 2.296 & 0.022 \\
$\mathrm{TR}=>$ PI & & & & 0.139 & 2.481 & 0.013 \\
$\mathrm{TR}=>$ BA & & & & -0.004 & -0.073 & 0.945 \\
$\mathrm{EX}=>$ PI & & & & -0.087 & -1.503 & 0.133 \\
$\mathrm{EX}=>$ BA & & & & 0.031 & 0.522 & 0.602 \\
\hline
\end{tabular}

Note: $\mathrm{TR}=$ trustworthiness, $\mathrm{AT}=$ attractiveness, $\mathrm{EX}=$ expertise, $\mathrm{WOM}=$ word of mouth, $\mathrm{PI}=$ purchase intention, $\mathrm{BA}=$ brand affection.

Source: Author's estimates.

Although the goodness-of-fit indices provide useful information about the overall model, it is worth noting that they are not enough to assess the mediating role of WOM in the proposed relationships. This is examined in the following section. 


\subsection{Mediation Analysis}

The proposed model predicts that the relationship between celebrity endorsement, purchase intention and brand affection is mediated by WOM. We test this using the well-established criteria put forward by Baron and Kenny (1986). The first step is to establish whether there is a substantial relationship between the dependent and independent constructs. The second step is to test for a substantial relationship between the dependent and mediator variables. The third step is to check for (i) an insignificant association between the dependent and independent constructs in the presence of the mediating variable (full mediation) and (ii) a decrease in the strength of this association in the presence of the mediating variable (partial mediation) (Table 5).

Table 5: Mediation analysis of specific indirect effect of celebrity endorsement on purchase intention and brand attitude

\begin{tabular}{lcccccc}
\hline \multirow{2}{*}{$\begin{array}{l}\text { Celebrity } \\
\text { endorsement }\end{array}$} & \multicolumn{3}{c}{$\begin{array}{c}\text { Indirect effect through WOM on } \\
\text { PI }\end{array}$} & \multicolumn{7}{c}{$\begin{array}{c}\text { Indirect effect through WOM on } \\
\text { BA }\end{array}$} \\
\cline { 2 - 7 } & Estimate & Lower & Upper & Estimate & Lower & Upper \\
\cline { 2 - 7 } & $0.264^{*}$ & 0.133 & 0.423 & $0.287^{*}$ & 0.147 & 0.445 \\
Trustworthiness & $0.147^{*}$ & 0.023 & 0.275 & $0.159^{*}$ & 0.026 & 0.302 \\
Attractiveness & $0.167^{*}$ & 0.034 & 0.293 & $0.181^{*}$ & 0.038 & 0.331 \\
Expertise & & &
\end{tabular}

Note: $\mathrm{BCCI}=$ bias-corrected confidence interval, * significant at $0.01,{ }^{* *}$ significant at 0.05 . Source: Author's estimates.

Following Holmbeck (1997), we conduct the mediation analysis using the bootstrapping approach (Iacobucci, 2008) to structural equation modeling. The indirect or mediated effects are calculated through a resampling of 3,000 using a 95 percent bias-corrected confidence interval.

\section{Discussion}

This study investigates the impact of three dimensions of celebrity endorsement - attractiveness, expertise and trustworthiness - on purchase intention and brand affection, with WOM taken as an intervening construct. Its results are in line with many other studies, including a metaanalysis conducted by Amos, Holmes and Strutton (2008), who show that the endorser's attractiveness, expertise and trustworthiness, when exercised separately, explain the effectiveness of such ads better than the celebrity's source credibility alone. 
The study's most important finding concerns the intervening role of WOM in the suggested relationships. It finds that WOM fully mediates the relationship between all three dimensions of celebrity endorsement and purchase intention and brand affection. These results support $\mathrm{Wu}$ and Wang's (2011) finding that e-WOM mediates the relationship between the endorser's attractiveness, trustworthiness and expertise and brand attitude, including brand affection, brand trust and customer intention to purchase.

The observed positive impact of all three dimensions (attractiveness, trustworthiness and expertise) on WOM reflects previous empirical evidence, such as Bush et al. (2005), who note that positive WOM is generated through normative and informational influences. Similarly, interpersonal influences, such as whether a consumer's peer group likes or dislikes a certain endorser, affect purchase decisions. Among young female consumers, products or services endorsed by their favorite endorser or athlete are more likely to generate positive WOM. Dix, Phau and Pougnet (2010) find support for the model proposed by Bush et al. (2005) in predicting the behavior of young Australian consumers. They find that sports celebrities as role models have considerable influence over WOM, which in turn affects brand loyalty, purchase intention and complaint behavior among consumers.

Of the three dimensions of celebrity endorsement, trustworthiness has the strongest impact on WOM, followed by expertise and attractiveness. According to Malik and Guptha (2014), the trustworthiness of the celebrity endorser helps strengthen consumers' faith in the brand being endorsed as well as positive changes in brand attitude. McGinnies and Ward (1980) find that the perceived trustworthiness of an endorser shapes consumer attitude and behavior more than perceived expertise. Wei and $\mathrm{Wu}$ (2013) point to credibility and trustworthiness as key factors shaping consumer attitude in Malaysia. Yoon, Kim and Kim (1998) underscore all three dimensions of celebrity endorsement with respect to positive brand beliefs among US and Korean consumers, although they too emphasize the relative importance of trustworthiness.

Based on the study's results, a firm's choice of celebrity endorser is important for developing positive WOM. Advertising agencies and clients in the US and Europe, for instance, prefer celebrity endorsers characterized by trustworthiness, familiarity and credibility (Erdogan, Baker \& Tagg, 2001). This makes it important for companies and advertising agencies to consider the trustworthiness and credibility associated with potential celebrity endorsers when designing advertising campaigns, to ensure they 
have the greatest possible impact on positive WOM, thereby increasing brand affection and purchase intentions.

\section{Study Limitations and Future Research}

Given the constraints related to time, accessibility and sampling frames, the study relied on convenient sampling to collect its data, which may affect the extent to which these results can be generalized. Although we have used cross-sectional data, future research could use longitudinal data to minimize common method bias.

Another aspect that could be incorporated is the cultural context. Considering that culture also shapes values, beliefs, attitudes, behavior and lifestyle, it may be interesting to gauge how this affects consumer response to different types of celebrities in Pakistan, including athletes, actors, singers, professionals, spokespersons, opinion makers and journalists. Future research could also assess whether celebrity endorsers associated with negative perceptions affect brand attributes such as brand affection, purchase intention and trust. Similarly, the effect of celebrity switching behavior on consumer behavior is an area worth examining. 


\section{References}

Agrawal, J., \& Kamakura, W. A. (1995). The economic worth of celebrity endorsers: An event study analysis. Journal of Marketing, 59(3), 56-62.

Ahmed, N., Farooq, O., \& Iqbal, J. (2014). Credibility of celebrity endorsement and buying intentions: An evidence from students of Islamabad, Pakistan. International Letters of Social and Humanistic Sciences, 20, 1-13.

Amos, C., Holmes, G., \& Strutton, D. (2008). Exploring the relationship between celebrity endorser effects and advertising effectiveness: A quantitative synthesis of effect size. International Journal of Advertising, 27(2), 209-234.

Anderson, E. W. (1998). Customer satisfaction and word of mouth. Journal of Service Research, 1(1), 5-17.

Anderson, J. C., \& Gerbing, D. W. (1988). Structural equation modeling in practice: A review and recommended two-step approach. Psychological Bulletin, 103(3), 411-423.

Baker, M. J., \& Churchill, G. A., Jr. (1977). The impact of physically attractive models on advertising evaluations. Journal of Marketing Research, 14(4), 538-555.

Bandura, A. (1967). Behavioral psychotherapy. Scientific American, 216(3), 78-86.

Bansal, H. S., \& Voyer, P. A. (2000). Word-of-mouth processes within a services purchase decision context. Journal of Service Research, 3(2), 166-177.

Baron, R. M., \& Kenny, D. A. (1986). The moderator-mediator variable distinction in social psychological research: Conceptual, strategic, and statistical considerations. Journal of Personality and Social Psychology, 51(6), 1173-1182.

Bergkvist, L., \& Zhou, K. Q. (2016). Celebrity endorsements: A literature review and research agenda. International Journal of Advertising, 35(4), 642-663. 
Bergkvist, L., Hjalmarson, H., \& Mägi, A. W. (2016). A new model of how celebrity endorsements work: Attitude toward the endorsement as a mediator of celebrity source and endorsement effects. International Journal of Advertising, 35(2), 171-184.

Biswas, D., Biswas, A., \& Das, N. (2006). The differential effects of celebrity and expert endorsements on consumer risk perceptions: The role of consumer knowledge, perceived congruency, and product technology orientation. Journal of Advertising, 35(2), 17-31.

Biswas, S., Hussain, M., \& O'Donnell, K. (2009). Celebrity endorsements in advertisements and consumer perceptions: A cross-cultural study. Journal of Global Marketing, 22(2), 121-137.

Bush, A. J., Martin, C. A., \& Bush, V. D. (2004). Sports celebrity influence on the behavior of Generation Y. Journal of Advertising Research, 44(1), 108-118.

Bush, V. D., Bush, A. J., Clark, P., \& Bush, R. P. (2005). Girl power and word-of-mouth behavior in the flourishing sports market. Journal of Consumer Marketing, 22(5), 257-264.

Chaudhuri, A., \& Holbrook, M. B. (2001). The chain of effects from brand trust and brand affect to brand performance: The role of brand loyalty. Journal of Marketing, 65(2), 81-93.

Cheung, G. W., \& Rensvold, R. B. (2002). Evaluating goodness-of-fit indexes for testing measurement invariance. Structural Equation Modeling, 9(2), 233-255.

Choi, S. M., \& Rifon, N. J. (2007). Who is the celebrity in advertising? Understanding dimensions of celebrity images. Journal of Popular Culture, 40(2), 304-324.

Cox, D. F. (1967). The audience as communicators. In D. F. Cox (ed.), Risk taking and information handling in consumer behavior (pp. 172-187). Boston, MA: Harvard University, Graduate School of Business Administration.

Daneshvary, R., \& Schwer, R. K. (2000). The association endorsement and consumers' intention to purchase. Journal of Consumer Marketing, 17(3), 203-213. 
Day, G. S. (1971). Attitude change, media and word of mouth. Journal of Advertising Research, 11(6), 31-40.

Dix, S., Phau, I., \& Pougnet, S. (2010). 'Bend it like Beckham': The influence of sports celebrities on young adult consumers. Young Consumers, 11(1), 36-46.

Erdogan, B. Z. (1999). Celebrity endorsement: A literature review. Journal of Marketing Management, 15(4), 291-314.

Erdogan, B. Z., Baker, M. J., \& Tagg, S. (2001). Selecting celebrity endorsers: The practitioner's perspective. Journal of Advertising Research, 41(3), 39-48.

Feick, L., \& Higie, R. A. (1992). The effects of preference heterogeneity and source characteristics on ad processing and judgements about endorsers. Journal of Advertising, 21(2), 9-24.

Feilitzen, C., \& Linne, O. (1975). Identifying with television characters. Journal of Communication, 25(4), 51-55.

Fireworker, R. B., \& Friedman, H. H. (1977). The effects of endorsements on product evaluation. Decision Sciences, 8(3), 576-583.

Fornell, C., \& Larcker, D. F. (1981). Evaluating structural equation models with unobservable variables and measurement error. Journal of Marketing Research, 18(1), 39-50.

Fraser, B. P., \& Brown, W. J. (2002). Media, celebrities, and social influence: Identification with Elvis Presley. Mass Communication and Society, 5(2), 183-206.

Friedman, H. H., \& Friedman, L. (1978). Does the celebrity endorser's image spill over the product? Journal of the Academy of Marketing Science, 6(4), 291-299.

Friedman, H. H., Termini, S., \& Washington, R. (1976). The effectiveness of advertisements utilizing four types of endorsers. Journal of Advertising, 5(3), 22-24.

Hamer, L. O., Liu, B. S.-C., \& Sudharshan, D. (1999). The effects of intraencounter changes in expectations on perceived service quality models. Journal of Service Research, 1(3), 275-289. 
Harrison-Walker, L. J. (2001). The measurement of word-of-mouth communication and an investigation of service quality and customer commitment as potential antecedents. Journal of Service Research, 4(1), 60-75.

Holmbeck, G. N. (1997). Toward terminological, conceptual, and statistical clarity in the study of mediators and moderators: Examples from the child-clinical and pediatric psychology literatures. Journal of Consulting and Clinical Psychology, 65(4), 599-610.

Hu, L.-T., \& Bentler, P. M. (1999). Cutoff criteria for fit indexes in covariance structure analysis: Conventional criteria versus new alternatives. Structural Equation Modeling, 6(1), 1-55.

Iacobucci, D. (2008). Mediation analysis. Thousand Oaks, CA: SAGE.

Jalilvand, M. R., \& Samiei, N. (2012). The impact of electronic word of mouth on a tourism destination choice: Testing the theory of planned behavior (TPB). Internet Research, 22(5), 591-612.

Kamins, M. A. (1989). Celebrity and non-celebrity advertising in a twosided context. Journal of Advertising Research, 29(3), 34-42.

Knoll, J., \& Matthes, J. (2017). The effectiveness of celebrity endorsements: A meta-analysis. Journal of the Academy of Marketing Science, 45(1), $55-75$.

Lafferty, B. A., \& Goldsmith, R. E. (1999). Corporate credibility's role in consumers' attitudes and purchase intentions when a high versus a low credibility endorser is used in the ad. Journal of Business Research, 44(2), 109-116.

Levin, G. (1988). Celebrity licensing gets tougher. Advertising Age, 59, 1 February.

Ling, I. L., \& Liu, Y. F. (2008). Comprehension and persuasion on advertising message: Heuristic-systematic model approach. Journal of Management, 25(5), 487-503.

MacCallum, R. C., Browne, M. W., \& Sugawara, H. M. (1996). Power analysis and determination of sample size for covariance structure modeling. Psychological Methods, 1(2), 130-149. 
Malik, G., \& Guptha, A. (2014). Impact of celebrity endorsements and brand mascots on consumer buying behavior. Journal of Global Marketing, 27(2), 128-143.

Mangold, W. G., Miller, F., \& Brockway, G. R. (1999). Word-of-mouth communication in the service marketplace. Journal of Services Marketing, 13(1), 73-89.

Marshall, D. W., \& Cook, G. (1992). The corporate (sports) sponsor. International Journal of Advertising, 11(4), 307-324.

Martin, C. A., \& Bush, A. J. (2000). Do role models influence teenagers' purchase intentions and behavior? Journal of Consumer Marketing, 17(5), 441-453.

Maxham, J. G. (2001). Service recovery's influence on consumer satisfaction, positive word-of-mouth and purchase intentions. Journal of Business Research, 54(1), 11-24.

Mazzarol, T., Sweeney, J. C., \& Soutar, G. N. (2007). Conceptualizing word-of-mouth activity, triggers and conditions: An exploratory study. European Journal of Marketing, 41(11-12), 1475-1494.

McCracken, G. (1989). Who is the celebrity endorser? Cultural foundations of the endorsement process. Journal of Consumer Research, 16(3), 310-321.

McGinnies, E., \& Ward, C. D. (1980). Better liked than right: Trustworthiness and expertise as factors in credibility. Personality and Social Psychology Bulletin, 6(3), 467-472.

McGuire, W. J. (1974). Psychological motives and communication gratification. In J. G. Blumler \& E. Katz (eds.), The uses of mass communications: Current perspectives on gratifications research (pp. 167-196). Beverly Hills, CA: SAGE.

Miles, J., \& Shevlin, M. (1998). Effects of sample size, model specification and factor loadings on the GFI in confirmatory factor analysis. Personality and Individual Differences, 25(1), 85-90.

Mizerski, R. W. (1982). An attribution explanation of the disproportionate influence of unfavorable information. Journal of Consumer Research, 9(3), 301-310. 
Nunnally, J. C., \& Bernstein, I. H. (1994). Psychometric theory (3rd ed.). New York: McGraw-Hill.

Ohanian, R. (1991). The impact of celebrity spokespersons' perceived image on consumers' intension to purchase. Journal of Advertising Research, 31(1), 46-54.

Okorie, N., Oyedepo, T., \& Akhidenor, G. (2012). The dysfunctional and functional effect of celebrity endorsement on brand patronage. Online Journal of Communication and Media Technologies, 2(2), 141-152.

Petty, R. E., Cacioppo, J. T., \& Schumann, D. (1983). Central and peripheral routes to advertising effectiveness: The moderating role of involvement. Journal of Consumer Research, 10(2), 135-146.

Pradhan, D., Duraipandian, I., \& Sethi, D. (2016). Celebrity endorsement: How celebrity-brand-user personality congruence affects brand attitude and purchase intention. Journal of Marketing Communications, 22(5), 456-473.

Rashid, M. Z. A., Nallamuthu, J., \& Sidin, S. M. (2002). Perceptions of advertising and celebrity endorsement in Malaysia. Asia Pacific Management Review, 7(4), 535-553.

Reichheld, F. F., \& Sasser, W. E., Jr. (1990). Zero defections: Quality comes to services. Harvard Business Review, 68(5), 105-111.

Schiffman, L. G., \& Kanuk, L. L. (2000). Consumer behavior (7th ed.). New York: Prentice Hall.

Sen, S., \& Lerman, D. (2007). Why are you telling me this? An examination into negative consumer reviews on the web. Journal of Interactive Marketing, 21(4), 76-94.

Sherman, S. P. (1985, August 19). When you wish upon a star. Fortune, 66-71.

Shukla, P. (2010). Impact of interpersonal influences, brand origin and brand image on luxury purchase intentions: Measuring interfunctional interactions and a cross-national comparison. Journal of World Business, 46(2), 242-252. 
Silverman, G. (2001). The secrets of word-of-mouth marketing: How to trigger exponential sales through runaway word of mouth. New York: AMACOM.

Spreng, R. A., Harrell, G. D., \& Mackoy, R. D. (1995). Service recovery: Impact on satisfaction and intentions. Journal of Services Marketing, 9(1), 15-23.

Steiger, J. H. (2007). Understanding the limitations of global fit assessment in structural equation modeling. Personality and Individual Differences, 42(5), 893-898.

Sternthal, B., Dholakia, R., \& Leavitt, C. (1978). The persuasive effect of source credibility: Tests of cognitive response. Journal of Consumer Research, 4(4), 252-260.

Stout, P. A., \& Moon, Y. S. (1990). Use of endorsers in magazine advertisements. Journalism and Mass Communication Quarterly, 67(3), 536-546.

Swan, J. E., \& Oliver, R. L. (1989). Post-purchase communications by consumers. Journal of Retailing, 65(4), 516-533.

Sweeney, J. C., Soutar, G. N., \& Mazzarol, T. (2008). Factors influencing word of mouth effectiveness: Receiver perspectives. European Journal of Marketing, 42(3-4), 344-364.

Till, B. D., \& Busler, M. (1998). Matching products with endorsers: Attractiveness versus expertise. Journal of Consumer Marketing, 15(6), 576-586.

Wang, X. (2011). The effect of inconsistent word-of-mouth during the service encounter. Journal of Services Marketing, 25(4), 252-259.

Wang, X., \& Yang, Z. (2010). The effect of brand credibility on consumers' brand purchase intention in emerging economies: The moderating role of brand awareness and brand image. Journal of Global Marketing, 23, 177-188.

Wei, K. K., \& Wu, Y. L. (2013). Measuring the impact of celebrity endorsement on consumer behavioral intentions: A study of Malaysian consumers. International Journal of Sports Marketing and Sponsorship, 14(3), 2-22. 
Westen, D. (1999). Psychology: Mind, brain and culture (2nd ed.). New York: John Wiley \& Sons.

Wu, P. C., \& Wang, Y.-C. (2011). The influences of electronic word-ofmouth message appeal and message source credibility on brand attitude. Asia Pacific Journal of Marketing and Logistics, 23(4), 448-472.

Xia, L., \& Bechwati, N. N. (2008). Word of mouse: The role of cognitive personalization in online consumer reviews. Journal of Interactive Advertising, 9(1), 3-13.

Yoon, K., Kim, C. H., \& Kim, M.-S. (1998). A cross-cultural comparison of the effects of source credibility on attitudes and behavioral intentions. Mass Communication and Society, 1(3-4), 153-173.

Zahaf, M., \& Anderson, J. (2008). Causality effects between celebrity endorsement and the intentions to buy. Innovative Marketing, 4(4), 57-65. 